\title{
Impact of sewage and mining activities on distribution of heavy metals in the water-soil-vegetation system
}

\author{
K. Semhi $\cdot$ R. Al Abri $\cdot$ S. Al Khanbashi
}

Received: 7 September 2011/Revised: 29 December 2012/ Accepted: 25 April 2013/Published online: 18 October 2013

(C) Islamic Azad University (IAU) 2013

\begin{abstract}
Several samples of groundwater and soils and plants have been collected from Sohar (Batina region, NE Oman), which is affected by various activities such as mining, agriculture, and sewage. To characterize quality of groundwater, As and $\mathrm{Cu}$ concentrations have been investigated in waters collected from different wells. Comparison of data with local and international standard values revealed that groundwater in Sohar region is characterized by lower concentrations in $\mathrm{Cu}$ and As compared with standards. In soils collected from the same area, concentrations of heavy metals have been measured in different fractions in order to investigate the mobility of such elements and risk of vulnerability in this area. A sequential extraction procedure has been applied to surface sediments to determine the partitioning of $\mathrm{Zn}, \mathrm{Cu}, \mathrm{Co}, \mathrm{Mn}, \mathrm{Fe}, \mathrm{Pb}, \mathrm{Cr}$, $\mathrm{Cd}$ and $\mathrm{Ni}$ among (1) exchangeable and acid-soluble phases, (2) Fe-Mn oxides, (3) organic matter and sulphides and (4) resistant phases. The results showed that the mobile fraction in the sewage area accounts only for $10 \%$ of the total concentration in sediments while in the $\mathrm{Cu}$ mining area, the contribution of the mobile fraction may exceed $10 \%$, especially for $\mathrm{Pb}, \mathrm{Mn}, \mathrm{Cd}, \mathrm{Cu}$ and $\mathrm{Co}$. Investigation of concentrations in $\mathrm{As}$ and $\mathrm{Cu}$ in plants collected from
\end{abstract}

K. Semhi $(\bowtie)$

Department of Earth Sciences, College of Science, Sultan Qaboos University, Al-Khod 123, P.O. Box 36,

Muscat, Sultanate of Oman

e-mail: semkhad@yahoo.fr

K. Semhi

4, Rue de Marlenheim, 67000 Strasbourg, France

R. Al Abri - S. Al Khanbashi

Ministry of Regional Municipality and Environmental

and Water Resources, Muscat, Sultanate of Oman mining and sewage areas revealed an important accumulation of these elements in leaves and may explain enrichment of As in shallow groundwater relative to deep groundwater. This investigation also showed that $\mathrm{Cu}$ is more available in sewage area than in mining zone, as opposed to As.

Keywords Batina - Arsenic A Arid S Sediments . Standard $\cdot$ Sohar $\cdot$ Mining

\section{Introduction}

Arid areas with high temperatures are characterized by high evapotranspiration rates accompanied with low precipitation, which explains the minimum recharge of aquifers and puts the water resources under depleting conditions. In the Sultanate of Oman, where there are more than 128,000 wells tapping the major aquifers, the total annual rainfall averages $100 \mathrm{~mm} /$ year with 0 and $350 \mathrm{~mm}$ extremes. As in most of arid countries, groundwater contamination poses a threat in the country. The most important source of degradation of groundwater in Oman is due to mining more than agriculture, oil industry and salt intrusion. Copper mining activities are well developed in Batina area. Several studies have been carried out to investigate the quality of groundwater in Oman (Sharma and AL-Busaidi 2001; Jamrah et al. 2004; Yaghi 2007). Jamrah et al. (2004) established vulnerability map for Barka region (north Batina, Oman) using DRASTIC vulnerability index method in GIS environment by using groundwater quality data such as chemical and biological parameters. These authors concluded that this region is partially highly vulnerable to pollution, especially the central part. In a previous study (Yaghi 2007), 
characterization of groundwater in Batina area revealed a contamination of most of the investigated groundwater with $\mathrm{Pb}$ and $\mathrm{Cr}$. Since degradation of quality of groundwater in Oman has been detected, the Ministry of Housing, Electricity and Water, the Ministry of Health, the Ministry of Commerce and Industry and the Ministry of Regional Municipality and Environmental and Water Resources started to give importance to testing and monitoring quality of waters in Oman. These different ministries have conducted several groundwater exploration projects throughout the Sultanate to study the availability and characteristics of groundwater resources in terms of its quantity and quality.

Although the several studies about the quality of water in Oman and in particular in Batina region, no investigation of As concentrations has been carried. Arsenic enters the environment through natural processes (Earth's crust and geothermal fluids) or via human activities such as those related to mining (Eisler 2004; Garelick et al. 2008). Thus, the main objective of the present study was to determine the concentrations of $\mathrm{As}$ and $\mathrm{Cu}$ in waters collected from wells affected by human activities such as mining, sewage and agriculture, and the mobility of $\mathrm{As}$ and $\mathrm{Cu}$ from soil to plants in the same zones with the same species of plants.

Investigation of quality of the groundwater during this study was carried out according to local standard considered by Oman and international standard fixed by WHO. Arsenic is a carcinogen that causes many cancers including skin and lung cancers. Some research concludes that even at the lower concentrations, there is still a risk of As contamination, leading to major causes of death. Arsenic contamination of groundwater is found in many countries. The most affected countries by As pollution in waters in the world include Bangladesh, India, China, Taiwan, Japan and Thailand.

Since soils have the capacity of sorbing trace elements, the second objective of this study is therefore to determine the partitioning of heavy metals in surface sediments collected from an area affected by $\mathrm{Cu}$ mining and in sediments collected from an area affected by sewage activities (Batina, NE Oman) in order to estimate their environmental mobility and the risk of pollution in this area.. Many different sequential extraction methods have been developed (e.g. Chester and Hughes 1967; Tessier et al. 1979; Karbassi 1998; Gleyzes et al. 2002; Ngole and Ekosse 2012). These methods involved determining the partitioning of trace elements in sediments in order to estimate their mobility and their availability in surface sediments related to environmental pollution risk, especially the anthropogenic contribution to the variation within a system.

In soils, trace elements may be associated with different phases, e.g. exchangeable, carbonate, Fe and Mn oxides, organic matter, sulphides and silicates. Their chemical form in the soil can influence their behaviour, such as their mobility, toxicity and bioavailability. Furthermore, several factors related to soil, such as soil $\mathrm{pH}$, Eh, clay contents, Mn oxide and oxidized Fe, organic matter as well as cation exchange capacity, were involved with distribution of heavy metals and their availability to plants in soils (Mench et al. 1997; de Matos et al. 2000; Martinez and Motto 2000; Sterckeman et al. 2000, Aydinalp and Marinova 2003; Pregitzer and King 2005). The exchangeable and acidextractable fractions such as carbonates are the mobile fractions that are easily bioavailable. The elements in this fraction may be affected by ion exchange and by changes in $\mathrm{pH}$. The reducible fraction includes $\mathrm{Mn}$ and $\mathrm{Fe}$ oxides that may become unstable under anoxic conditions while the oxidizable fraction accounts for the fraction bound to organic matter and sulphides. During sequential extraction, the silicate minerals and crystalline Fe/Mn oxides are not easily dissolved and represent the most resistant phases. The elements in these phases are not released under natural conditions.

The trace elements investigated during this study were $\mathrm{Cd}, \mathrm{Co}, \mathrm{Cr}, \mathrm{Cu}, \mathrm{Ni}, \mathrm{Pb}$ and $\mathrm{Zn}$. This investigation included major elements such as $\mathrm{Fe}$ and $\mathrm{Mn}$ since they are important in trapping of trace elements.

Geology and hydrogeology of the studied area

The geological formations of Batina have undergone substantial tectonic activity involving faulting and thrusting. The geologic setting of basin consists of crystalline bedrock formations, mainly ophiolites, mantled by unconsolidated alluvium deposits. The ophiolites impede groundwater flow and define the base of the hydrogeological system. They formed when the Tethyan oceanic crust abducted against Arabian Plate in the Late Cretaceous between 90 and $105 \mathrm{Ma}$ (Robertson et al. 1990; Hanna 1995). Ophiolites consist in sequences of dunite, harzburgite, gabbros, sheeted dykes and pillow lavas. It makes the main source for the alluvium formed as a result of ophiolites weathering. The limestones are deposited in the Tertiary under shallow marine environment consequent to sea transgression.

The alluviums, formed in the quaternary and unconformably rest on the ophiolites represent the main source of the groundwater in the region and comprise gravelly poorly sorted sedimentary units that directly overlie the ophiolites in the major drainage system. The area is generally arid with varying rainfall. Total annual rainfall averages $100 \mathrm{~mm} /$ year with 0 and $350 \mathrm{~mm}$ extremes.

\section{Materials and methods}

The material of this study is composed of waters, sediments and plants collected from the same area. 


\section{Waters}

During this study, waters were collected from several wells in different locations penetrating the alluvium-aquifer in Sohar (north of Muscat area) (Fig. 1). These locations include sewage treatment areas, agriculture areas and $\mathrm{Cu}$ mining areas. Waters were also collected from 2 wells at downstream of these different areas and are considered a control area.

The different water samples have been collected in 500-ml polypropylene containers. Instantaneous site analysis was carried out for $\mathrm{pH}$, conductivity and temperature. For the laboratory analysis, water samples were vacuumfiltered through a membrane filter with $0.45-\mu \mathrm{m}$ pore size.
Laboratory analyses were conducted within 3 days of sample collection.

\section{Soils}

In parallel to waters, sediments were collected from the same locations in Sohar (north of Muscat area) (Fig. 1). These locations include sewage treatment areas and $\mathrm{Cu}$ mining areas. Five representative sediment samples were collected from both areas. From each sample, an amount of about $500-1,000 \mathrm{~g}$ of sediments was collected from the surface of soils (within $0-10 \mathrm{~cm}$ ) and packed in polythene bags.

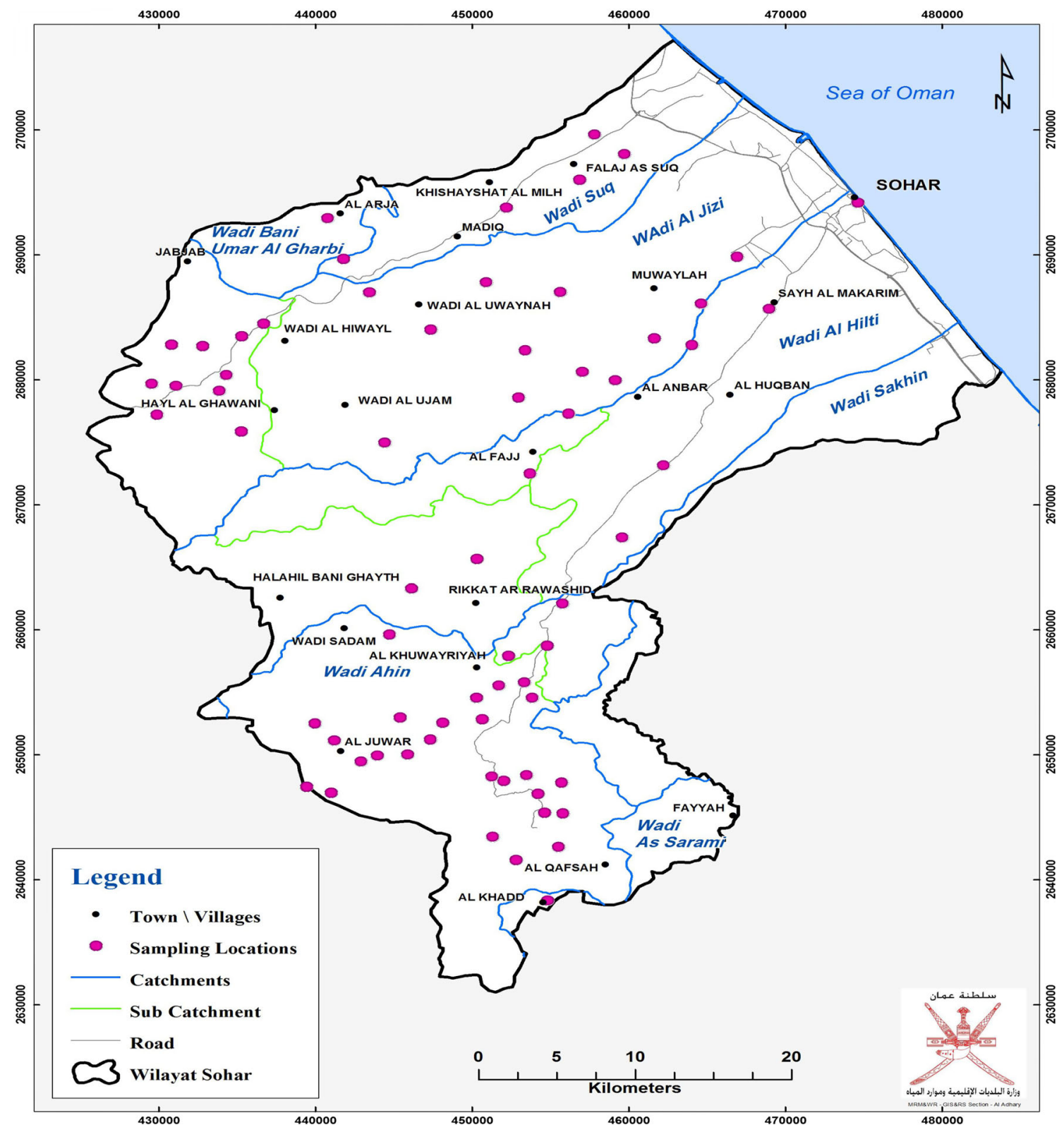

Fig. 1 Batina sampling location 
The soil samples were dried in the oven at $60{ }^{\circ} \mathrm{C}$ for $24 \mathrm{~h}$ and sifted to less than $63 \mu \mathrm{m}$ and homogenized in an agate mill. Two batches of each soil sample were used: one batch was used for identification of mineral composition using X-ray diffraction whereas from the other batch about $250 \mathrm{~g}$ of each sample was used for chemical analysis.

Plants

As for soils, plants were collected from $\mathrm{Cu}$ mining area and from sewage area. The leaves of about twenty individual plants from each plant sample were removed randomly and grouped in five separate batches. The plants of each batch were processed and analysed separately, so that the chemical data for the plants collected from each area represented an average of five sets of plant individuals in each case. In other words, instead of repeating the analyses for control of the analytical uncertainty, we managed the analytical reproducibility in analysing systematically five batches of each plant at each step and averaged the data within a $2 \sigma$ error. In summary, plant data in Table 2 represent actually an average measure of 100-125 individual plants split into 5 independent batches.

The collected plants were first washed five times with demineralized water. This washing was followed by a gentle ultrasonic treatment in a bath for about $10 \mathrm{~min}$ to remove any solid mineral particles that could have adhered at the surface of the plants. After removing from ultrasonic bath, the plants were washed again with demineralized water.

\section{Sequential extraction experiment}

From each investigated site, 5 samples of soil were collected from the upper horizons (about $0-10 \mathrm{~cm}$ depth) to determine the partitioning of heavy metals, in the soil. The sequential extraction scheme adopted in this study is shown in Fig. 2 according to BCR's guidelines (the Community Bureau of Reference sequential extraction scheme) and to Álvarez et al. (2002). The different steps were proposed by Tessier et al. (1979), Jennifer and Jicheng (1993) and Ahnstrom and Parker (1999). All the operations were carried out in 50-ml polypropylene centrifuge tubes and Teflon containers. The initial mass of sediment was $1.0 \pm 0.0001 \mathrm{~g}$. The extracts were separated from the solid residue by centrifugation at 4,000 rpm for $30 \mathrm{~min}$. After each step, the solution was filtered by suction through a $0.45-\mu \mathrm{m}$ Millipore filter, and the filtrate collected in a polyester container. Then, the solutions for each step were
Fig. 2 Sequential extraction scheme used in this study

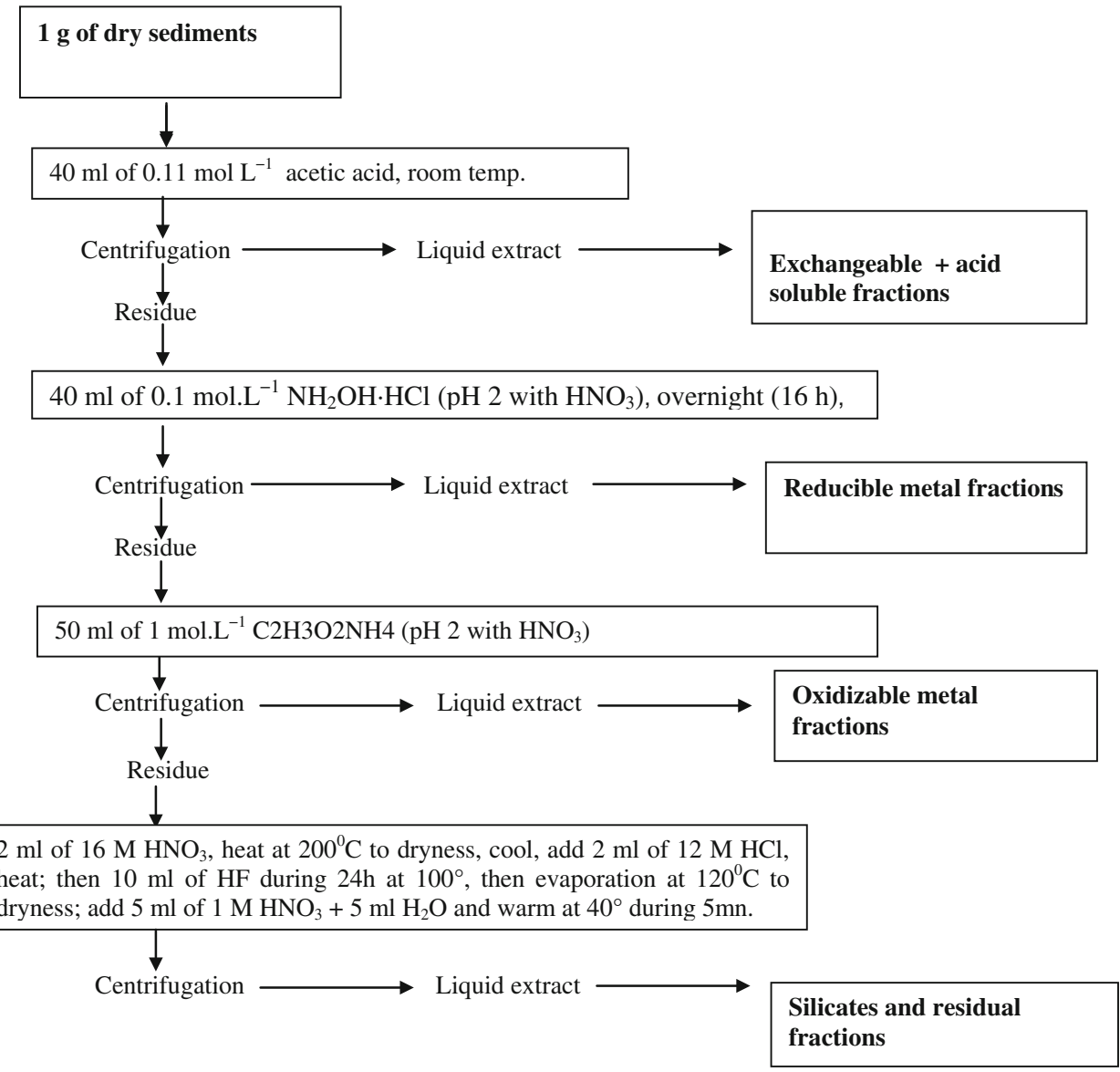


prepared accordingly for ICP-MS measurement. The extraction sequence in 4 steps includes four reagents (weakest to strongest): (1) acetic acid $\left(\mathrm{CH}_{3} \mathrm{COOH}\right)$ to extract all exchangeable, acid-soluble and water-soluble metals, (2) hydroxylammonium chloride $\left(\mathrm{NH}_{2} \mathrm{OH} \cdot \mathrm{HCl}\right)$ to extract all reducible metals, (3) ammonium acetate $\left(\mathrm{CH}_{3} \mathrm{COONH}_{4}\right)$ and hydrogen peroxide $\left(\mathrm{H}_{2} \mathrm{O}_{2}\right)$ to extract all oxidizable metals and (4) HF which dissolve increasingly more resistant mineral phases (see Fig. 2).

Mobile fraction (exchangeable, acid-soluble and watersoluble metal fraction)

$1 \mathrm{~g}$ of dry soil $(<63 \mu \mathrm{m}$ fraction) was extracted into 100 -ml polypropylene centrifuge tube with $40 \mathrm{ml}$ of acetic acid $(0.11 \mathrm{~mol} / \mathrm{l})$. The samples were shaken for $16 \mathrm{~h}$ (overnight) at room temperature $\left(\approx 20^{\circ} \mathrm{C}\right)$ on an end-over-end mechanical shaker at $40 \mathrm{rpm}$. The extract was separated from the solid residue by centrifugation at $4,000 \mathrm{rpm}$ (SIGMA model 3-15). The residue was washed with $20 \mathrm{ml}$ distilled water by shaking for $15 \mathrm{~min}$, centrifuged and the washings discarded.

\section{Reducible metal fraction}

The above residue was extracted overnight (16 h) with $40 \mathrm{ml}$ of $0.1 \mathrm{~mol} / 1 \mathrm{NH}_{2} \mathrm{OH} \cdot \mathrm{HCl}\left(\mathrm{pH} 2\right.$ with $\left.\mathrm{HNO}_{3}\right)$. The separation procedure was then performed as described in the previous step.

\section{Oxidizable metal fraction}

The above residue was treated by careful addition of $10 \mathrm{ml}$ of $30 \% \mathrm{H}_{2} \mathrm{O}_{2}$ during $1 \mathrm{~h}$ with occasional manual shaking. Digestion was continued by heating the tube at $85^{\circ} \mathrm{C}$ in a water bath for $1 \mathrm{~h}$, and then, the tube contents were reduced to 1-2 $\mathrm{ml}$. A second $10-\mathrm{ml}$ aliquot of hydrogen peroxide was added and the tube was again heated at $85^{\circ} \mathrm{C}$ for $1 \mathrm{~h}$. Afterwards, the volume was reduced as before. $50 \mathrm{ml}$ of ammonium acetate $(1 \mathrm{~mol} / \mathrm{l}$, adjusted to $\mathrm{pH} 2$ with nitric acid) was added to the cool, moist residue. The sample was then shaken, centrifuged and the extract separated as described in step one.

\section{Total residual metal}

Soil residues from sequential extraction procedure were digested in HF acid for total metal determination.

\section{Availability of heavy metals}

Mobility of elements from soil solution to roots has been calculated by normalization of concentrations of different elements investigated in this study in plants collected from different areas to the concentrations of heavy metals in the most mobile and unstable fraction. This unstable fraction includes the exchangeable and acid-soluble fractions in the soil plus the reducible and the oxidizable fractions.

Analytical material

The mineralogical composition of the soil samples was determined by X-ray diffraction.

Digestion of plants was carried out following Semhi et al. (2009). The analytical procedure started with drying the plant batches at $60{ }^{\circ} \mathrm{C}$ for $24 \mathrm{~h}$ and weighed them afterwards. Then, each weighed plant amount was ashed in a Pt crucible at about $600{ }^{\circ} \mathrm{C}$ for $45 \mathrm{~min}$. The ash was transferred into a Teflon beaker and digested in ultrapure concentrated $\mathrm{HNO}_{3}$ at a temperature of about $70{ }^{\circ} \mathrm{C}$ for $24 \mathrm{~h}$ and more if needed. The solution was then slowly evaporated to dryness by closing the beakers. Ten drops of $\mathrm{HClO}_{4}$ were added afterwards to ensure dissolution of all remaining organic material, and the aliquot was evaporated again to dryness. The obtained solution was then prepared for analysis by dissolving the dried material with a known volume of $1 \mathrm{~N} \cdot \mathrm{HNO}_{3}$.

Plants were analysed for $\mathrm{As}, \mathrm{Cu}, \mathrm{Cd}, \mathrm{Co}, \mathrm{Cr}, \mathrm{Cu}, \mathrm{Ni}, \mathrm{Pb}$ and $\mathrm{Zn}$. Waters were analysed only for $\mathrm{As}$ and $\mathrm{Cu}$ while the different fractions extracted during the sequential extraction were analysed for $\mathrm{Cd}, \mathrm{Co}, \mathrm{Cr}, \mathrm{Cu}, \mathrm{Fe}, \mathrm{Mn}, \mathrm{Ni}, \mathrm{Pb}$ and Zn.

Arsenic and $\mathrm{Cu}$ concentrations in plants and waters were determined using inductively coupled plasma optical emission spectrometry (ICP-OES). Analytical precision ranged between 5 and $10 \%$.

The concentrations of $\mathrm{Cd}, \mathrm{Co}, \mathrm{Cr}, \mathrm{Cu}, \mathrm{Fe}, \mathrm{Mn}, \mathrm{Ni}, \mathrm{Pb}$ and $\mathrm{Zn}$ in plants and the different fractions were determined using the inductively coupled plasma atomic emission spectroscopy (ICP-MS). Analytical precision ranged between 5 and $10 \%$.

\section{Results and discussion}

The average chemical concentrations of the different elements in water, soil and plant samples are provided in Tables 1, 2 and 3 respectively.

Waters

The results of the measured in situ parameters including $\mathrm{pH}$, temperature $(\mathrm{T})$, electrical conductivity (EC) and the chemical composition of groundwater are given in Table 1. The data showed that the $\mathrm{pH}$ of waters collected from wells of mining area is about 6.6-8.6. The conductivity also 
Table 1 Average chemical composition of groundwater collected from Batina; concentrations are expressed (in $\mathrm{ppb})$

nd not determined

\begin{tabular}{|c|c|c|c|c|c|c|c|}
\hline Waters from: & $\mathrm{EC}$ & $\mathrm{T}\left({ }^{\circ} \mathrm{C}\right)$ & $\mathrm{PH}$ & Depth (m) & Water level (m) & $\mathrm{Cu}(\mathrm{ppb})$ & As (ppb) \\
\hline \multicolumn{8}{|l|}{$\mathrm{Cu}$ mining } \\
\hline 1 & 3,900 & 31.3 & 8.6 & 17.8 & 16.4 & 6.57 & 0.86 \\
\hline 2 & 1,357 & 33.6 & 7.32 & 15 & 12.5 & 19.31 & 1.26 \\
\hline 3 & 8,700 & 34 & 7.5 & 18.7 & 11.7 & 5.355 & 0.43 \\
\hline 4 & 3,900 & 31.3 & 8.6 & 17.8 & 16.4 & 0 & 0.21 \\
\hline 5 & 3,400 & 30.9 & 7.92 & 17.4 & 15.7 & 3.39 & 0.42 \\
\hline 6 & nd & nd & nd & nd & nd & 5.09 & 1.77 \\
\hline 7 & nd & nd & nd & nd & nd & 32.09 & 0.66 \\
\hline 8 & nd & nd & nd & nd & nd & 82.00 & 1.69 \\
\hline 9 & nd & nd & nd & nd & nd & 19.44 & 3.85 \\
\hline \multicolumn{8}{|l|}{ Sewage } \\
\hline 1 & 1,000 & 31.1 & 8.4 & 17.5 & 16 & nd & 0.26 \\
\hline 2 & 5,400 & 30.4 & 7.7 & 16.5 & 15.4 & nd & 0.23 \\
\hline \multirow[t]{3}{*}{3} & 9,000 & 31.1 & 7.6 & 17.8 & 16.5 & nd & 0.32 \\
\hline & nd & nd & nd & nd & nd & nd & 0.26 \\
\hline & nd & nd & nd & nd & nd & nd & nd \\
\hline \multicolumn{8}{|l|}{ Agriculture } \\
\hline 1 & 5,200 & 30 & 7.6 & 7 & 5.1 & nd & 0.40 \\
\hline \multirow[t]{3}{*}{2} & 6,400 & 30.3 & 7.6 & 8.5 & 6.2 & nd & 0.44 \\
\hline & nd & nd & nd & nd & nd & 10.53 & 0.09 \\
\hline & nd & nd & nd & nd & nd & 2.71 & 0.07 \\
\hline \multicolumn{8}{|l|}{ Control } \\
\hline 1 & 670 & 30 & 8.38 & 18.5 & 15 & nd & 0.21 \\
\hline 2 & 365 & 33 & 9 & 25 & 12 & 0.20 & 0.64 \\
\hline
\end{tabular}

Table 2 Average chemical composition of sediments collected from Batina in different fractions; concentrations are expressed (in ppm)

\begin{tabular}{|c|c|c|c|c|c|c|c|c|c|}
\hline \multirow[t]{2}{*}{ Soils from } & \multicolumn{9}{|c|}{ (In ppm) } \\
\hline & $\mathrm{Cd}$ & Co & $\mathrm{Cr}$ & $\mathrm{Cu}$ & $\mathrm{Fe}$ & Mn & $\mathrm{Ni}$ & $\mathrm{Pb}$ & $\mathrm{Zn}$ \\
\hline \multirow[t]{4}{*}{ Control } & 0.05 & 0.11 & 0.05 & 0.05 & 0.38 & 13.81 & 6.14 & 0.27 & 1.37 \\
\hline & 1.05 & 63.70 & 121.23 & 11.60 & $5,176.96$ & 946.23 & 553.46 & 47.14 & 108.89 \\
\hline & 0.30 & 0.89 & 5.95 & 13.99 & 0.89 & 1.79 & 2.08 & 5.06 & 2.08 \\
\hline & 0.90 & 10.02 & 994.99 & 13.23 & $400,962.31$ & 486.07 & $1,766.04$ & 5.21 & 86.41 \\
\hline \multicolumn{10}{|l|}{$\mathrm{Cu}$ mining } \\
\hline F1 & 0.059 & 0.235 & 0.176 & 0.059 & 0.705 & 24.965 & 4.582 & 0.176 & 30.486 \\
\hline $\mathrm{F} 2$ & 0.291 & 2.035 & 0.872 & 0.872 & 10.756 & 404.942 & 17.151 & 0.291 & 3.779 \\
\hline F3 & 0.302 & 0.603 & 0.603 & 5.430 & 1.810 & 2.112 & 1.810 & 4.525 & 2.413 \\
\hline $\mathrm{F} 4$ & 1.160 & 10.354 & 633.727 & 46.702 & $65,203.008$ & 753.942 & $1,204.425$ & 5.113 & 117.81 \\
\hline \multicolumn{10}{|c|}{ Sewage area } \\
\hline F1 & 0.040 & 0.080 & 0.040 & 0.040 & 0.320 & 9.564 & 1.240 & $<\mathrm{nd}$ & 0.200 \\
\hline $\mathrm{F} 2$ & $<\mathrm{nd}$ & $<$ nd & $<\mathrm{nd}$ & 0.098 & $<\mathrm{nd}$ & $<$ nd & $<\mathrm{nd}$ & $<$ nd & $<\mathrm{nd}$ \\
\hline F3 & 0.133 & 0.199 & 0.133 & 1.195 & 0.332 & 0.266 & 0.531 & 0.929 & 0.332 \\
\hline $\mathrm{F} 4$ & 5.195 & 8.760 & 985.383 & 39.929 & $68,936.084$ & 152.839 & $1,279.908$ & 4.991 & 91.367 \\
\hline
\end{tabular}

Nd not determined

measured in the field showed large fluctuation in waters collected from wells in the different sectors. The lowest value is 365 and it was measured in waters collected from wells in the agriculture area. The highest value was measured in waters collected from wells in the sewage plant area.

Concentrations of As in waters collected from wells affected by $\mathrm{Cu}$ mining range from 0.21 to $3.85 \mathrm{ppb}$ while $\mathrm{Cu}$ 
Table 3 Average chemical composition of plants collected from Batina; concentrations are expressed (in ppm) for the concentrations in the whole plant and in ppb for the concentrations of $\mathrm{Cu}$ and $\mathrm{As}$ in the different parts of the plant

\begin{tabular}{|c|c|c|c|c|c|c|c|c|c|c|c|c|c|c|}
\hline \multirow[t]{3}{*}{ Plants from } & \multicolumn{8}{|c|}{ (in ppm) } & \multicolumn{6}{|l|}{ (in $\mathrm{ppb}$ ) } \\
\hline & \multirow[t]{2}{*}{$\mathrm{Cd}$} & \multirow[t]{2}{*}{ Co } & \multirow[t]{2}{*}{$\mathrm{Cr}$} & \multirow[t]{2}{*}{$\mathrm{Fe}$} & \multirow[t]{2}{*}{$\mathrm{Mn}$} & \multirow[t]{2}{*}{$\mathrm{Ni}$} & \multirow[t]{2}{*}{$\mathrm{Pb}$} & \multirow[t]{2}{*}{$\mathrm{Zn}$} & \multicolumn{3}{|l|}{$\mathrm{Cu}$} & \multicolumn{3}{|l|}{ As } \\
\hline & & & & & & & & & Leaves & Stems & roots & Leaves & Stems & roots \\
\hline $\mathrm{Cu}$ mining area & 0.05 & 0.189 & 0.805 & 91.74 & 7.308 & 1.384 & 0.201 & 33.86 & 61,473 & 6,696 & 9,856 & 1,196 & 78 & 87 \\
\hline Sewage area & 0.095 & 0.13 & 0.639 & 61.07 & 14.75 & 0.9 & 0.107 & 12.23 & 10,132 & nd & 5,530 & 71 & & 40 \\
\hline \multirow[t]{2}{*}{ Agricultural area } & nd & nd & nd & nd & nd & nd & nd & nd & 4,930 & nd & nd & 40 & nd & nd \\
\hline & nd & nd & nd & nd & nd & nd & nd & nd & nd & nd & nd & nd & nd & \\
\hline
\end{tabular}

$N d$ not determined

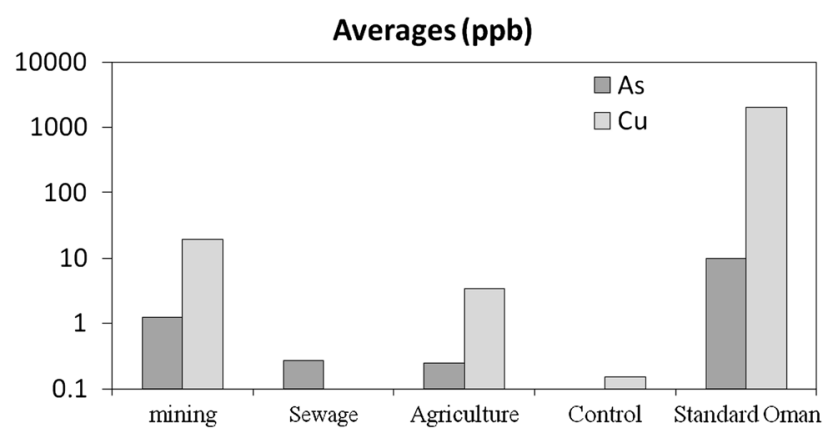

Fig. 3 Average concentration of $\mathrm{As}$ and $\mathrm{Cu}$ in soils collected from different areas

concentrations range from less than detection limit to $82 \mathrm{ppb}$ (Table 1). Concentrations of As in waters collected from wells affected by sewage range from less than detection limit to $0.32 \mathrm{ppb}$ while $\mathrm{Cu}$ concentrations are less than detection limit. The waters collected from wells in areas affected by agriculture are characterized by $\mathrm{Cu}$ concentrations ranging from less than detection limit to $10.53 \mathrm{ppb}$, and As from 0.07 to $0.44 \mathrm{ppb}$. The concentrations of $\mathrm{Cu}$ in waters collected from control areas are from less than detection limit to $0.20 \mathrm{ppb}$ while As concentrations are from 0.21 to $0.64 \mathrm{ppb}$. Higher As concentrations in Batina region were observed in the $\mathrm{Cu}$ mining area and may be associated with $\mathrm{Cu}$ mining activities (Fig. 3). Waters in wells from agriculture and from the control areas have higher As concentrations than in sewage areas and may reflect an anthropogenic source although they are below the toxicity characteristics of waters. Nevertheless, the source of As in waters in Batina region is not yet well known and need more investigations.

The standards for maximum concentrations of As in drinking water have been changed from $150 \mu \mathrm{g} / \mathrm{l}$ in 1903 fixed by report of the Royal Commission on As Poisoning in the UK to $50 \mu \mathrm{g} / \mathrm{l}$ in 1942. The FAO has also considered a limit of $50 \mu \mathrm{g} / \mathrm{l}$ for arsenic in groundwater. In 1993, the WHO (1993) guideline value for arsenic in drinking water was reduced from 50 to $10 \mu \mathrm{g} / \mathrm{l}$. Most western countries adopted this limit in their current drinking water standards (Yamamura 2003). On the other hand, many affected countries still operate a standard of $50 \mu \mathrm{g} / \mathrm{l}$. Before 2006, the EPA (USEPA 1996, 2000, 2001) recommended a limit of $5 \mu \mathrm{g} / \mathrm{L}$ (Fig. 4).

Since 2001, As standard limit approved and fixed by US Environmental Protection Agency (USEPA) is within 3 to $20 \mu \mathrm{g} / \mathrm{l}$ (USEPA 2001) and fixed to $10 \mu \mathrm{g} / \mathrm{l}$ by WHO (2001). This range is much exceeded in some countries such as Bangladesh where standard for As in drinking water is fixed at $50 \mu \mathrm{g} / \mathrm{l}$ (Gaus et al. 2003; Hoque et al. 2008). According to standard limits established by Oman, concentration of As in drinking waters was fixed at $0.01 \mathrm{ppb}$. The standard limits established by World Health Organization for $\mathrm{Cu}$ is about $2 \mathrm{ppb}$ in groundwater as what was established by Oman for $\mathrm{Cu}$ (Fig. 4).

The results of this study are low compared with the standard acceptable levels of drinking water and irrigation. Conductivity could be used to give an idea of the amount of dissolved chemicals in water, and presence of $\mathrm{Na}, \mathrm{K}$ and $\mathrm{Cl}$. The elevated values of EC in waters of two wells from sewage area and one well from mining area suggested that there is inorganic pollution compared with waters of the other wells. Nevertheless, these high values of EC do not correlate with the high As concentrations and may suggest different sources of pollution in Batina area. The vertical distribution of As revealed its enrichment in shallow wells sampled from $\mathrm{Cu}$ mining areas relative to deep wells (Fig. 5). A different tendency is observed for wells sampled from sewage area, where concentration of As in deep wells is higher than in shallow wells. Irregular tendency concerns waters collected from agriculture areas in lack of an important number of samples. The correlation of $\mathrm{Cu}$ concentrations with depth is more irregular than As concentrations.

To interpret the enrichment of As in shallow wells of $\mathrm{Cu}$ mining area, relationship of concentrations with $\mathrm{pH}$ has also been investigated. High concentrations of As in waters of mining area were measured in waters with high $\mathrm{pH}$ (Fig. 5). There is no correlation between $\mathrm{pH}$ and waters collected from wells of sewage areas. Desorption of As from minerals in shallow waters or precipitation in deep waters may explain the vertical distribution of As in wells of $\mathrm{Cu}$ mining areas. 
Fig. 4 Standard data of a $\mathrm{Cu}$ and $\mathbf{b}$ As
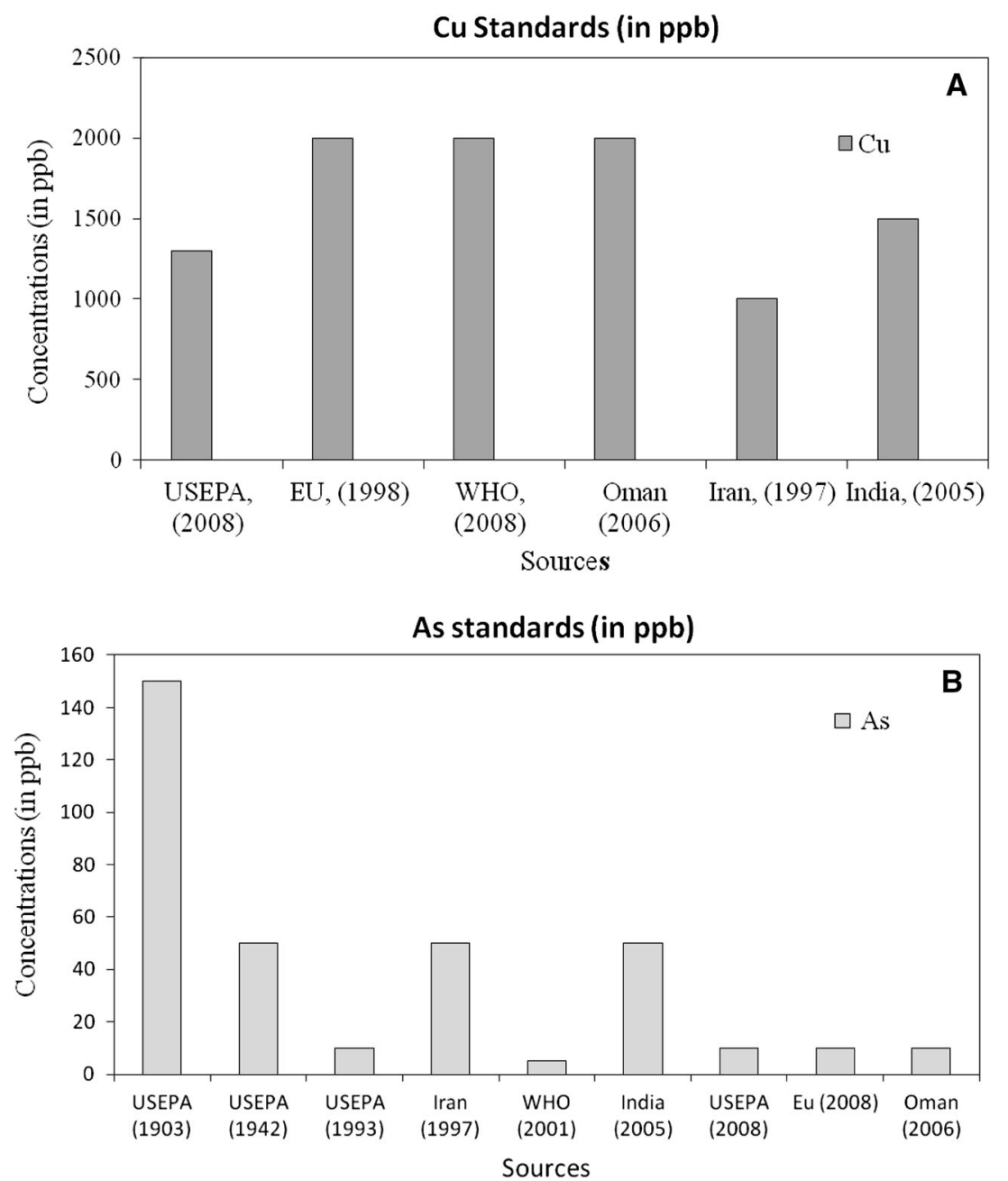

However, since As from minerals (desorption) hypothesis is not enough to explain the whole concentrations in waters, investigation of As in plants has been carried out (see below). A previous study of $\mathrm{K} / \mathrm{Rb}$ ratios in aqueous systems (Chaudhuri et al. 2007) revealed that high ratios of $\mathrm{K} / \mathrm{Rb}$ are strongly suggestive that the metal or semi-metal present in the aqueous system must take into consideration the role of all these from plants. Plants can cumulate large amount of nutrients either from soils or from atmospheric inputs (Mandre 1995; Mandre et al. 2000). Transformation and decay of plants may consider a considerable source of elements in surface waters and shallow groundwater.

\section{Soils}

The soil of the Batina region consisted in a sandy loamy soil. Its mineral composition determined by XRD consisted in quartz, calcite, dolomite, feldspar and palygorskite with some minor minerals. Measurement of $\mathrm{pH}$ revealed alkaline soils ( $\mathrm{pH}$ about 7.8-8.9).

The average chemical concentration of the different elements in the different fractions separated from the soil is provided in Table 2. The concentrations of various elements in the soil are given as per gram of soil.

Acid-soluble and exchangeable fraction (bioavailable), $F_{1}$

Determination of concentration of heavy metals in this fraction may evaluate the mobility and availability of these elements for uptake and risk for the environment. The concentrations of heavy metals in the exchangeable and acid-soluble fraction removed by acetic acid during this study are low compared with the other fractions. However, the affinity order of different metals and $\mathrm{Fe}$ and $\mathrm{Mn}$ for exchangeable and acid-soluble fraction in soils collected from the area affected by $\mathrm{Cu}$ mining is as follows: $\mathrm{Mn}>\mathrm{Zn}>\mathrm{Ni}>\mathrm{Fe}>\mathrm{Co}>\mathrm{Cu}>\mathrm{Cr}>\mathrm{Pb}>\mathrm{Cd}$

(Table 2). In soils collected from area affected by sewage, the descending affinity order for exchangeable and acidsoluble fraction is as follows: $\mathrm{Mn}>\mathrm{Fe}>\mathrm{Ni}>\mathrm{Zn}>$ $\mathrm{Co}>\mathrm{Cr}>\mathrm{Pb}>\mathrm{Cu}>\mathrm{Cd}$ (Fig. 6). Availability of heavy metals in soils of $\mathrm{Cu}$ mining area is more important than in soils of sewage area. Significant difference between the two areas concerns $\mathrm{Zn}$ and $\mathrm{Cr}$. 

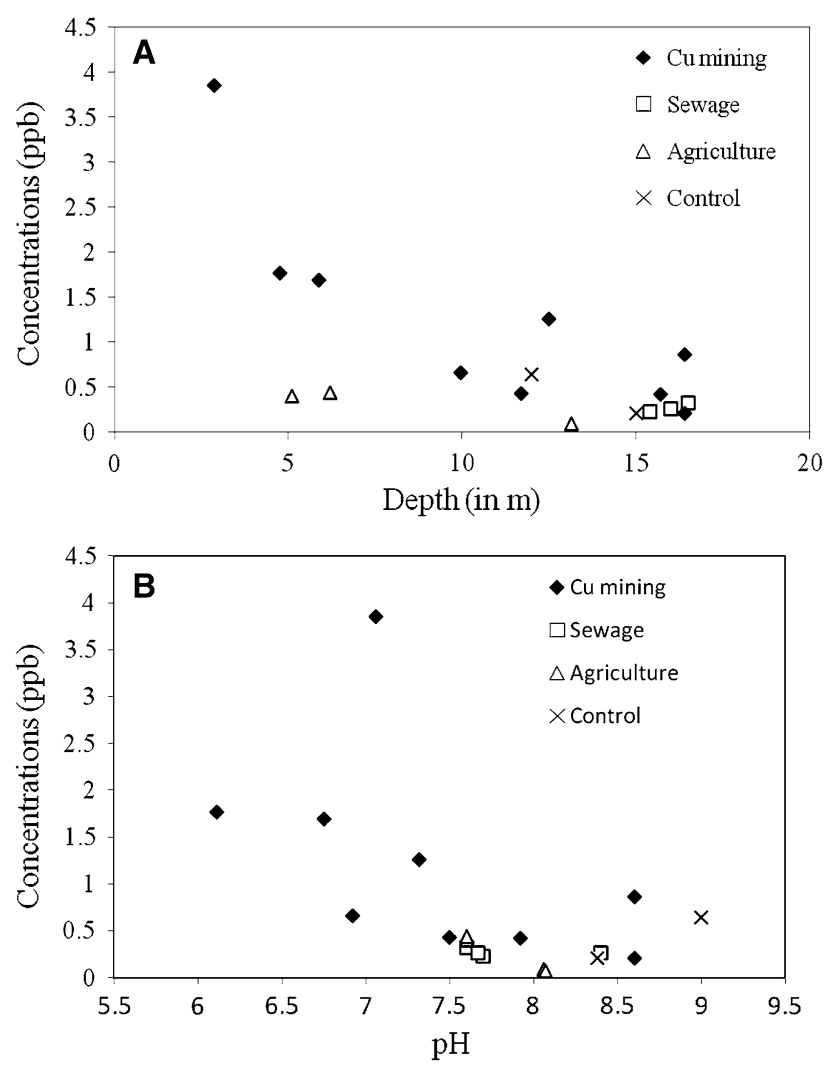

Fig. 5 Variation in As concentrations with a depth and $\mathbf{b} \mathrm{pH}$

Reducible fraction (iron and $M n$ oxide), $F_{2}$

This fraction includes mainly heavy metals carried by Fe-Mn oxides. Determination of concentration of heavy metals and $\mathrm{Fe}$ and $\mathrm{Mn}$ in this fraction extracted from soils collected from $\mathrm{Cu}$ mining area showed the following order: $\mathrm{Mn}>\mathrm{Fe}>\mathrm{Ni}>$ $\mathrm{Zn}>\mathrm{Co}>\mathrm{Cu}>\mathrm{Cr}>\mathrm{Pb}>\mathrm{Cd}$ (Table 2, Fig. 6). In the soils collected from sewage area, the concentrations of heavy metals and $\mathrm{Fe}$ and $\mathrm{Mn}$ in the reducible fraction are distributed as follows: $\mathrm{Fe}>\mathrm{Mn}>\mathrm{Ni}>\mathrm{Zn}>\mathrm{Cu}>\mathrm{Cr}>$ $\mathrm{Pb}>\mathrm{Cr}>\mathrm{Co}>\mathrm{Cd}$.

\section{Oxidizable fraction (fraction bound to organic matters and sulphides), $F_{3}$}

This fraction includes heavy metals bound to sulphide and organic matter. These metals are temporarily inaccessible. With time, decomposition of organic matrix under modification of anoxic conditions induces their release to water or to other fractions.

The results of this study showed the affinity order of different metals for oxidizable fraction in soil affected by $\mathrm{Cu}$ mining as follows: $\mathrm{Cu}>\mathrm{Mn}>\mathrm{Fe}>\mathrm{Zn}>\mathrm{Co}>\mathrm{Ni}>$ $\mathrm{Pb}>\mathrm{Cr}>\mathrm{Cd}$; and in soils affected by sewage, the order is as follows: $\mathrm{Cu}>\mathrm{Pb}>\mathrm{Zn}>\mathrm{Fe}>\mathrm{Ni}>\mathrm{Mn}>\mathrm{Co}>\mathrm{Cr}=\mathrm{Cd}$ (Table 2, Fig. 6).
Silicate and residual fraction, $F_{4}$

Silicate and residual fraction of metals is the most chemically stable fraction and does not represent a threat for the environment. Either in soils affected by $\mathrm{Cu}$ mining or soils affected by sewage, the residual fraction is the most enriched in elements compared with other fractions (Table 2, Fig. 6). The abundance of Fe and $\mathrm{Mn}$ and heavy metals in this fraction from soils of $\mathrm{Cu}$ mining area is as follows: $\mathrm{Fe}>\mathrm{Mn}>\mathrm{Cr}>\mathrm{Ni}>\mathrm{Cu}>\mathrm{Zn}>\mathrm{Pb}$, while in soils from sewage area, it is as follows: $\mathrm{Fe}>\mathrm{Ni}>\mathrm{Cr}>\mathrm{Mn}>$ $\mathrm{Zn}>\mathrm{Cu}>\mathrm{Pb}$.

These results show that most of heavy metals (more than $90 \%$ ) in the sewage area are carried in the residual fraction. Their concentrations in the other fractions are not significant. Their mobility is small and does not represent any risk to the environment. In the opposite, in the soils collected from $\mathrm{Cu}$ mining area, although the important fraction is the resistant one, heavy metals are not only carried by this fraction, but they are also distributed significantly in the other fractions. It is the case of Co which has an important concentration in the oxidizable fraction in one soil and an important concentration in reducible fraction in another soil. This study also revealed that a significant amount of $\mathrm{Cd}$ is carried by both reducible and oxidizable fractions (about $36 \%$ of the total concentration), but less than in the resistant fraction $(64 \%)$. The study of Páez-Osuna and Osuna-López (1990) in surface sediments showed that most of $\mathrm{Cd}$ was found in association with the oxidizable fraction in contrast to other studies (Helsinger and Friedman 1982; Rapin et al. 1983; Abaychi and Douabul 1986) where most of Cd was found in association with the carbonates and reducible fractions.

As it was reported by (Tessier et al. 1979; Páez-Osuna and Osuna-López 1990), the results of our study showed that the second non-negligible fraction of $\mathrm{Cu}$ is associated with organic complexes. The sequential extraction in the soil collected from $\mathrm{Cu}$ area revealed that $\mathrm{Mn}$ has a significant concentration in reducible and oxidizable fraction. These results are in contrast to those of Páez-Osuna and Osuna-López (1990) who found that $\mathrm{Mn}$ is distributed between the exchangeable and the oxidizable phases. Similar results about $\mathrm{Pb}$ which is significantly carried by oxidizable fraction have been found by Páez-Osuna and Osuna-López (1990) who reported that more than $10 \%$ of $\mathrm{Pb}$ in sediments is associated with organic complexes in contrast to Rapin et al. (1983) and Abaychi and Douabul (1986) who showed that the fraction of $\mathrm{Pb}$ associated with $\mathrm{Fe} / \mathrm{Mn}$ oxides and hydroxides is significant. Our study revealed that $\mathrm{Pb}$ is equally carried by oxidizable fraction (organic complexes) and resistant phases. $\mathrm{Zn}$ is carried at significant concentrations in acid exchangeable fraction in one soil and in oxidizable fraction in the other soil. In both 
Fig. 6 Average geochemical distribution of elements (in ppm) among the different fractions (F1, F2, F3 and F4) extracted from surface sediments collected in: a control area, $\mathbf{b} \mathrm{Cu}$ mining area and c sewage area
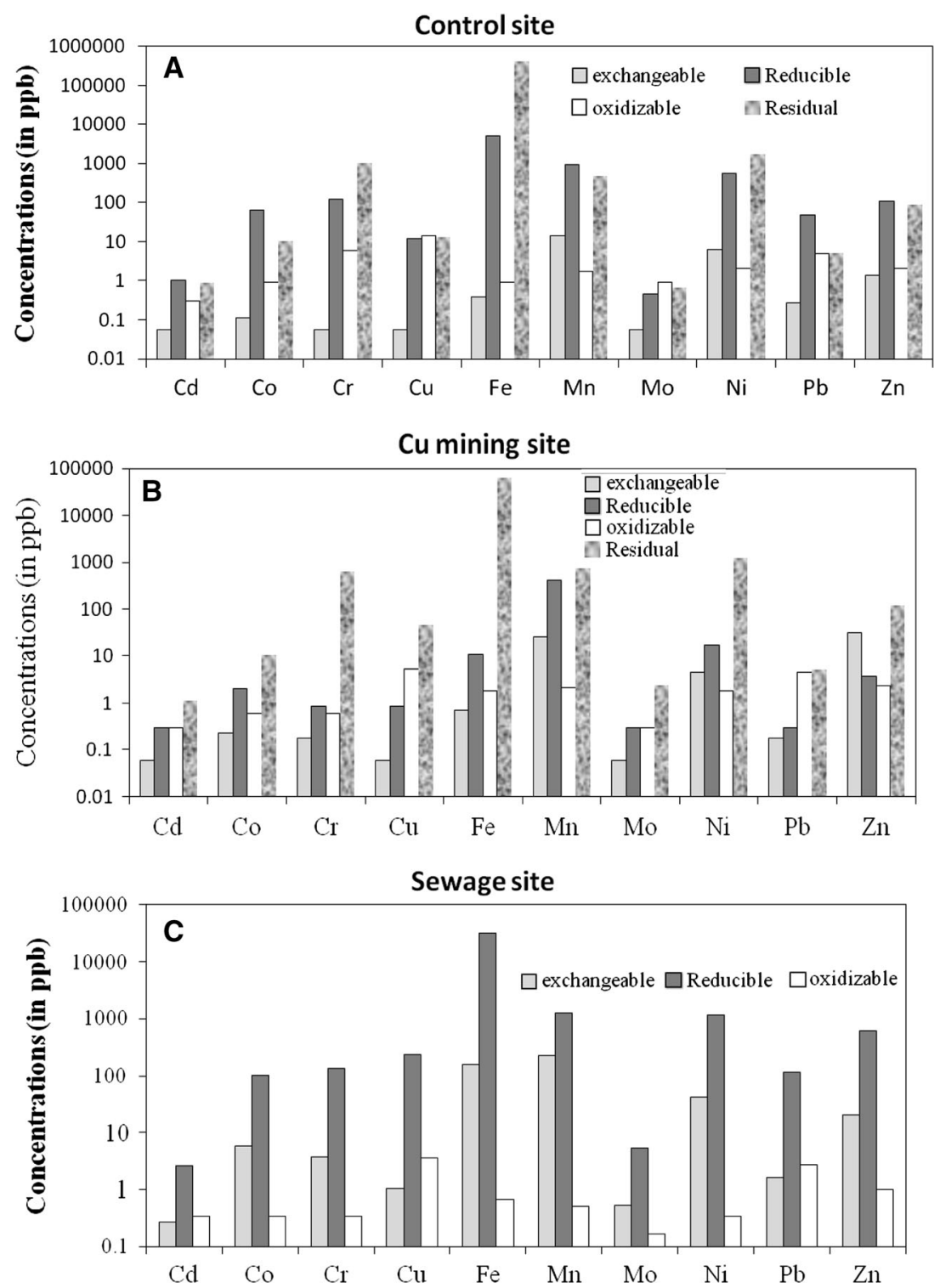

soils, a significant amount of $\mathrm{Zn}$ was found in the residual fraction. Similar results have been found by Zerbe et al. (1999).

In summary, if we calculate the total amount of mobile fraction which includes all fractions except the resistant one, we may evaluate the rate of instability of elements and the risk to environment if anoxic conditions or $\mathrm{pH}$ change.

Investigation revealed that in the area affected by sewage, the unstable fractions are negligible (less than $10 \%$ of the total) compared with the resistant fraction, except for $\mathrm{Pb}$ whose distribution in the mobile fraction is about $16 \%$. In this area, elements have a low environmental availability and are poorly affected by human activity.

In soils collected from mining area, the most mobile elements consist in $\mathrm{Pb}, \mathrm{Mn}, \mathrm{Cd}, \mathrm{Cu}$ and $\mathrm{Co}$. The preferential association of $\mathrm{Cd}, \mathrm{Cu}$ and $\mathrm{Pb}$ is for oxidizable and organic fraction. The association of $\mathrm{Mn}$ and $\mathrm{Co}$ is significant in reducible fraction.

These results indicated that these elements may be a threat to the environment in Batina region if anoxic conditions or $\mathrm{pH}$ change. In a previous study (Yaghi 2007), characterization of groundwater in Batina area revealed a contamination of most of analysed groundwater in $\mathrm{Pb}$ and $\mathrm{Cr}$. This study also revealed higher concentrations of $\mathrm{Cu}$ in groundwater collected from wells in Batina region compared to standards.

\section{Plants}

The data concern the same species of plants Rhazya stricta, but collected from two different areas: (1) areas affected by $\mathrm{Cu}$ mining as for groundwater and (2) areas affected by sewage 


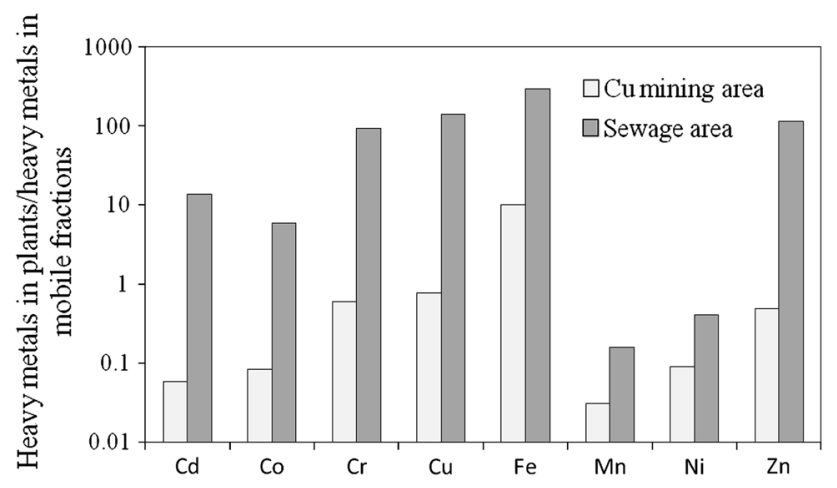

Fig. 7 Concentrations of heavy metals normalized to those in the mobile fraction $(\mathrm{F} 1+\mathrm{F} 2+\mathrm{F} 3)$ removed from the soil

activities. The average chemical concentrations of the different elements are given as micrograms $(\mu \mathrm{g})$ of element per gram (g) of dry plant material (Table 3 ).

Plants which grew in sewage area are more enriched in elements than plants collected from soils of the copper mining area although the mobile fraction removed from these last soils are more enriched in heavy metals than the mobile fraction removed from soils of sewage area (Table 3). The partitioning of heavy metals showed that availability of elements is more important in soils collected from $\mathrm{Cu}$ mining area than in soils from sewage area (Fig. 7).

Availability and uptake of heavy metals by plants do not depend only on their content in the soil, but also on $\mathrm{pH}$ of soil, organic matter and amount of clays in the soil (Singh 1994). The same type of soils has been identified in sewage and $\mathrm{Cu}$ mining area. The difference in the amount of elements uptake by the same species of plants collected from these two areas may reflect differences in physicochemical properties, especially $\mathrm{pH}$ rather than in the amount of organic matter in the soil since sewage soils contain important amount of organic matter (Lindsay and Logan 1998; Zhang et al. 2007) highly than other areas. Organic matter is known to immobilize heavy metals in soils and reduce their uptake by plants which it is in opposite of our results. The organic matter can also complex with heavy metals found in soils (Weng et al. 2002; Silveira et al. 2003; Tukura et al. 2007; Ashworth and Alloway 2008) reducing heavy metal pollution. Several authors have studied the effect of sewage sludge on soil physical, chemical and biological properties (King and Morris 1972, Melo et al. 1994, 2002). The study of Melo et al. (2002) revealed that sewage increased soil organic matter and $\mathrm{pH}$ and enzyme activities in soils. Investigation of effect of sewage on soils by Al-Wabel et al. (1998) revealed that the $\mathrm{pH}$ values of treated soils by sewage sludge decreased and the concentrations of heavy metals increased in the treated layers of soil compared to the untreated layers. Our results may reflect a change in the $\mathrm{pH}$ more pronounced in sewage area than in mining area. Future research will focus more on the physicochemical of the system plant-soil-waters in Batina region.

\section{Conclusion}

Comparison with standards showed that there is no risk in groundwater of Sohar area in term of $\mathrm{As}$ and $\mathrm{Cu}$ levels since all concentrations are below the toxicity characteristics. The weak correlation between $\mathrm{Cu}$ and $\mathrm{As}$ revealed that $\mathrm{As}$ is not only released from the industry of $\mathrm{Cu}$ but from other sources. Organic inputs such as plants have to be more investigated.

In industrial and sewage areas of Batina region, the availability of $\mathrm{Fe}, \mathrm{Mn}$ and trace elements determined by sequential extractions revealed that during each step, the most mobile elements in $\mathrm{Cu}$ mining area relative to each other consisted of (1) $\mathrm{Mn}$ and $\mathrm{Zn}$ more available than the other elements because they are more released by acetic acid, (2) $\mathrm{Mn}$ and $\mathrm{Cd}$ are susceptible to be released when $\mathrm{pH}$ conditions change, (3) $\mathrm{Cu}$ and $\mathrm{Cd}$ are more kept in oxidizable fraction than in the other elements, (4) more than $90 \%$ of total Fe and $\mathrm{Mn}$ are strongly kept in resistant phases and about more than $50 \%$ of total concentrations of $\mathrm{Cu}, \mathrm{Co}, \mathrm{Cd}$ and $\mathrm{Zn}$ are carried in this fraction. Lead is equally distributed between resistant fractions $(50 \%)$ and the other fractions.

In the sewage area, sequential extractions revealed that $\mathrm{Pb}$ is the most mobile element compared with the other elements which are significantly carried in the resistant fraction. The resistant phases in these soils are more enriched in $\mathrm{Fe}$ and $\mathrm{Ni}$ than in the other elements.

Acknowledgments The authors would like to thank sincerely Ahmed Al Bulushi and Hommoud Al Rejaiby from Ministry of Regional Municipality and Environmental and Water Resources, for their collection of samples. We would also like to thank Ahmad Al Mewali (Department of Engineering, Ministry of Municipalities) and Mahfoodh Al-shuely (Department of Engineering, Ministry of Defence) for chemical analysis.

\section{References}

Abaychi JK, Douabul AAZ (1986) Trace element geochemical associations in the Arabian Gulf Associations géochimiques des éléments traces dans le Golfe d'Oman. Mar Poll Bull 17(8):353-356

Ahnstrom ZS, Parker DR (1999) Development and assessment of a sequential extraction procedure for the fractionation of soil cadmium. Soil Sci Soc Am J 63:1650-1658

Álvarez EA, Mochon MC, Jimenez sanchez JC, Ternero Rodríguez M (2002) Heavy metal extractable forms in sludge from wastewater treatment plants. Chemosphere 47(7):765-775

Al-Wabel MI, AL-Omran AM, Shalaby AA, Choudhary MI (1998) Effect of sewage sludge on some chemical properties of calcareous sandy soils. Soil Sci Plant Anal 29(17 and 18):2713-2724

Ashworth DJ, Alloway BJ (2008) Influence of dissolved organic matter on the solubility of heavy metals in sewage-sludgeamended soils. Commun Soil Sci Plant Anal 39:538-550 
Aydinalp C, Marinova S (2003) Distribution and forms of heavy metals in some agricultural soils. Pol J Environ Stud 12(5):629-633

Chaudhuri S, Clauer C, Semhi K (2007) Plant decay as a major control of river dissolved potassium: a first estimate. Chem Geol Isot Geosci Sect 243(1-2):178-190

Chester R, Hughes RM (1967) A chemical technique for the separation of ferromanganese minerals, carbonate minerals and adsorbed trace elements from Pelagic Sediments. Chem Geol 2:249-262

De Matos AT, Fontes MPF, Da Costa LM, Martinez MA (2000) Mobility of heavy metals as related to soil chemical and mineralogical characteristics of Brazilian soils. Environ Pollut 111:429-435

Eisler R (2004) Arsenic hazards to humans, plants, and animals from gold mining. Rev Environ Contam Toxicol 180:133

Garelick H, Jones H, Dybowska A, Valsami-Jones E (2008) Arsenic pollution sources. Environ Contam Toxicol 197:17-60

Gaus I, Kinniburgh DG, Talbot JC, Webster R (2003) Geostatistical analysis of As concentration in groundwater in Bangladesh using disjunctive kriging. Environ Geol 44:939-948

Gleyzes C, Tellier S, Astruc M (2002) Fractionation studies of trace elements in contaminated soils and sediments: a review of sequential extraction procedures. Trends Anal Chem 21:451-467

Hanna S (1995) Field guide to the geology of Oman. International Printing Press, Ruwi 178p

Helsinger MH, Friedman GM (1982) Distribution and incorporation of trace elements in the bottom sediments of the Hudson River and its tributaries. Northeast Environ Sci 1:33-47

Hoque MA, Khan AA, Shamsudduha M, Hossain MS, Islam T, Chowdhury SH (2008) Near surface lithology and spatial variation of arsenic in the shallow groundwater: southeastern Bangladesh. Environ Geol 56(8):1687-1695

Jamrah A, AL-Futaisi A, Rajmohan N, AL-Yaroubi S (2004) Assessment of groundwater vulnerability in the coastal region of Oman using DRASTIC index method in GIS environment. Environ Monit Assess 147(1-3):125-138

Jennifer MJ, Jicheng H (1993) Sequential extraction method: a review and evaluation. Environ Geochem Health 15(2-3):185

Karbassi AR (1998) Geochemistry of Ni, Zn, Cu, Pb, Co., Cd, V, Mn, $\mathrm{Fe}, \mathrm{Al} \& \mathrm{Ca}$ in sediments of North Western part of the Persian Gulf. Int J Environ Stud 54:205-212

King LD, Morris HD (1972) Land disposal of liquid sewage sludge. III. The effect on soil $\mathrm{pH}$, manganese, zinc, and growth and chemical composition of Rye (Cecale cereale, L). J Environ Qual 1:425-429

Lindsay BJ, Logan J (1998) Field response of soil physical properties to sewage sludge. J Environ Qual 27(3):534-542

Mandre M. (1995). Changes in the nutrient composition of trees. In: Mandrc M (ed) Dust pollution and forest ecosystems. A study of conifers in an alkalized Environment. Institute of Ecology 3, Tallinn, p 44-65

Mandre M, Klõ Seikok J, Ots A (2000) The effect of cement dust on the growth, content of nutrients and carbohydrates in various organs of five conifer species. Balt For 6(11):2000

Martinez CE, Motto HL (2000) Solubility of lead, zinc and copper added to mineral soils. Environ Pollut 107:153-158

Melo WJ, Marques MO, Santiago G, Chelli RA, Leite SAS (1994) Efeito de Doses Crescentes de Lodo de Esgoto Sobre Fraçoes da Matéria Organica e CTC de Um Latossolo Cultivado Dom Canade-açucar. R Bras Ci Solo 18:449-455

Melo WJ, Marques MO, Ferreira ME, De Melo GMP, Melo VP (2002) Chemical properties and enzyme activity in a sewage sludgetreated soil. Commun Soil Sci Plant Anal 33(9 and 10):1643-1659

Mench M, Baize D, Mocquot B (1997) Cadmium availability to wheat in five soil series from the Yonne District, Burgundy, France. Environ Pollut 95(1):93-103

Ngole VM, Ekosse GIE (2012) Copper, nickel and zinc contamination in soils within the precincts of mining and landfilling environments. Int J Environ Tech 9(3):485-494
Páez-osuna F, Osuna-lópez JI (1990) Heavy metals distribution in geochemical fractions of surface sediments from the lower gulf of california. Anales del Instituto de Ciencias del Mar y Limnología Universidad Nacional Autónoma de México 17(2):287-298

Pregitzer KS, King JS (2005) Effects of soil temperature on nutrient uptake. Ecological studies. In: BassiriRad H (ed) Nutrient acquisition by plants an ecological perspective, vol 181 . Springer, Berlin

Rapin F, Nembrini GP, Fostner U, Garcia JI (1983) Heavy metals in marine sediment phases determined by sequential chemical extraction and their interaction with interstitial water. Environ Technol Lett 4(8-9):387-396

Robertson AHF, Searle MP, Ries A (1990). The geology and tectonics of the Oman region (ed). Geological Society of London Special Publication 49, Oxford, p 845

Semhi K, Chaudhuri S, Clauer N (2009) Fractionation of rare-earth elements in plants during an experimental growth in varied clay substrates. Appl Geochem 24(3):447-453

Sharma RS, AL-Busaidi TS (2001) Groundwater pollution due to a tailings dam. Eng Geol 60(1-4):235-244

Silveira MLA, Alleoni LRF, Guilherme LRG (2003) Biosolids and heavy metals in soils. Sci Agric (Piracicaba, Braz.) 60(4):793-806

Singh BR (1994) Trace element availability to plants in agricultural soils, with special emphasis on fertilizer inputs. Environ Rev/ Dossiers Environ 2(2):133-146

Sterckeman T, Douay F, Proix N, Fourrier H (2000) Vertical distribution of $\mathrm{Cd}, \mathrm{Pb}$, and $\mathrm{Zn}$ in soils near smelters in the north of France. Environ Pollut 107:377-389

Tessier AP, Campbell GC, Bisson M (1979) Sequential extraction procedure for the speciation of particulate Trace Metals. Anal Chem 51(7):844-851

Tukura BW, Kagbu JA, Gimba CE (2007) Effects of pH and total organic carbon (TOC) on the distribution of trace metals in Kubanni dam sediments, Zaria, Nigeria. Sci World J 2(3): $1597-6343$

US EPA (Environment Protection Agency) (1996) USEPA drinking water regulations and health advisories, EPA 822-B-96-002, Washington, DC

US EPA (Environmental Protection Agency) (2000) Technologies and costs for removal of arsenic from drinking water. EPA 815R00028 prepared by Malcolm Pirnie

US EPA (Environment Protection Agency) (2001) National primary drinking water regulations; arsenic and clarifications to compliance and new source contaminants monitoring. Final rule

Weng L, Temminghoff EJM, Lofts S, Tipping E, Vanriemsdijk WH (2002) Complexation with dissolved organic matter and solubility control of heavy metals in a sandy soil. Environ Sci Technol 36(22):4804-4810

WHO (World Health Organization) (1993) Guidelines for drinking water quality, vol. 1: recommendations, 2nd edn. WHO, Geneva

WHO (World Health Organization) (2001) Arsenic contamination of drinking water in Bangladesh, Fact sheet \#210. www.who.int/ inf-fs/en/fact210.html

Yaghi B (2007) Heavy metal levels in tap water in Batina region, Oman. Int J Environ Pollut 31(1-2):219-229

Yamamura S (2003) Drinking water guidelines and standards. In: Hashizume $\mathrm{H}$ and Yamamura S (eds) Arsenic, water, and health: the state of the art, chap. 5. World Health Organisation, Geneva, Switzerland

Zerbe J, Sobczyński T, Elbanowska H, Siepak J (1999) Speciation of heavy metals in bottom sediments of lakes. Pol J Environ Stud 8(5):331-339

Zhang H, Sun L, Sun T, Ma G (2007) Principal Physicochemical Properties of Artificial Soil Composed of Fly Ash, Sewage Sludge and Mine Tailing. Bull Environ Contam Toxicol 79:562-565 